\title{
Association between Hormonal Contraception and Blood Glucose Level Among Women of Childbearing Age in Sangkrah Community Health Center, Surakarta
}

\author{
Brillian Ferika Sabania'), Bhisma Murti²), Diffah Hanim³) \\ 1)2)Faculty of Medicine, Sebelas Maret University \\ 3)Faculty of Nutrition, Sebelas Maret University
}

\begin{abstract}
Background: Hormonal contraceptive contains estrogen and progesterone hormones. These hormones are hypothesized to affect blood glucose level. This study aimed to determine the association between hormonal contraception and blood glucose level among childbearing aged women.

Subjects and Method: This was an analytic observational study with cross-sectional design. The study subjects were childbearing aged women who used and did not use hormonal contraceptive in Sangkrah community health center, Surakarta. A total sample of 47 people consisting of 32 hormonal contraceptive users and 15 non users were selected for study by fixed exposure sampling. The data were collected by questionnaire, interview, anthropometric measurement, and direct measurement of blood glucose level. The data were analyzed using a multiple linear regression with SPSS for Windows.

Results: Women of childbearing age who used hormonal contraceptive had an average blood glucose $26 \mathrm{mg} / \mathrm{dL}$ higher than the non-users of hormonal contraceptive $(b=26.18 ; 95 \% \mathrm{CI}=15.03$ to $37.33 ; \mathrm{p}<0.001$ ). These estimates had controlled for the effect of confounding variables (i.e. Body Mass Index and diabetes mellitus risk factors).

Conclusion: There is a positive and statistically significant association between the use of hormonal contraceptive and blood glucose level among women of childbearing age.
\end{abstract}

Keywords: hormonal contraception, blood glucose level

Correspondence:

Novreka Pratiwi Sipayung. Faculty of Medicine, Sebelas Maret University

\begin{tabular}{l} 
BACKGROUND \\
\hline Human population growth is getting in- \\
creasing. By the end of 2012 it is recorded \\
that the world population has reached 7 \\
billion people, whereas Indonesia is in the \\
$4^{\text {th }}$ place after China, India, and USA (Biro \\
Pusat Statistik, 2013). The high population \\
growth rate of a country certainly is follow- \\
ed by its advantages and disadvantages. The \\
advantage is the higher number of human \\
resources will strengthen national defense. \\
Indonesia will be a developed country for \\
sure if the resource can be well managed \\
However, a large number of human resour-
\end{tabular}

ce is also followed by a large number of demography problems.

To make the best use of Human resource management in Indonesia, therefore government finds it necessary to anticipate the occurrence of population explosion. Family Planning program or Keluarga Berencana $(\mathrm{KB})$ is an effort to control population desity by lowering down the fertility rate using contraceptive (Glasier dan Gebbie, 2006). The program is positively responded with the emerging of Indonesian people's awarness to participate in KB program. Central Bureau of Statistics states that in 2011 
Indonesian Journal of Medicine (2016), 1(1): 1-11 https://doi.org/10.26911/theijmed.2016.01.01.01

the percentage of married women aged 1549 who used contraceptives was $61.34 \%$, it increased from 2010 that was only $60.94 \%$ (Biro Pusat Statistik, 2012).

Currently there are various types of contraceptives methods such as IUD, sterilization, condome, hormonal contraceptive either injected, oral/ pill, or implant. The most used method of contraceptive is hormonal contraceptive. Users of hormonal contraceptives in Indonesia based on National Dempography and Family Planning Agency (BKKBN) is $83.29 \%$ in January 2012. The most commonly used hormonal contraceptives are injection $48.72 \%$, oral/ pill $27.72 \%$, implant $6.85 \%$. In Central Java, users of hormonal contraceptives reach $86.35 \%$, and $56.33 \%$ of them use injection method, $19.91 \%$ use oral method/ pill, and $10.11 \%$ use contraceptive implant (BKKBN, 2012). Hormonal contraceptives are mostly used because it is easy to get, widely varied, highly effective (Wiegratz dan Christian, 2011).

Hormonal contraceptives are distinguished based on their hormone content into 2 categories namely combined contraceptives (with estrogen and progesterone content) and progesterone contraceptives. Progesterone contraceptives are likely to be developed since a number of side effects are generated from contraceptives with estrogen (Ahrendt dan Bühling, 2010). However, the effect of progesterone contraceptives also needs further study, since progesterone shows antagonist nature toward insulin so it may increase blood glucose level (Chrousos, 2007). Therefore, the writer is interested to analyze the correlation between hormonal contraception and blood glucose level.$$
\text { SUBJECTS AND METHOD }
$$

The study was an analytic observational study with cross-sectional study approach. The study was employed to investigate the asso-
}

ciation between study factors by simultaneously observing those factors on individuals of single population within one period of time (Murti, 2003). Certainly, not all subjects should be assessed on the same day or time, however the factors to be investigated are measured according to condition or status of observation time (Sastroasmoro, 2008)

The study was conducted during April and May 2013 in Sangkrah Community Health Center Surakarta. The place of study was chosen because Sangkrah Community Health Center covers the most number of people in the area of Surakarta city which subordinates 3 urban communities: Sangkrah, Kedung Lumbu, and Semanggi urban communities.

The targeted population was women of childbearing age who took hormonal contraceptives in Sangkrah Community Health Center Surakarta. The accessible population was women of childbearing age in Sangkrah Community Health Center Surakarta. The population of women of childbearing age who took hormonal contraceptives in Sangkarah Community Health Center Surakarta by the end of 2012 was 3,040 people out of totally 5,333 contraceptives users. Therefore it was exceedingly sufficient for collecting sample in the location.

The sample was women of childbearing age who took hormonal contraceptives in Sangkrah Community Health Center Surakarta who were willing to be assessed, with the following criteria:

a. Inclusion Criteria:

1) Women of childbearing age (not yet menopause)

2) Age 20-49 years old

According to PERKENI consensus 2006, the assessment of diabetes mellitus risk factors is conducted toward people aged 20 years old and above. The IMT is a nutrition status 
assessment conducted to those who age more (Depkes, 2008). Menopause happens commonly in the age 50 years old. Considering that it was determined that the sample age ranged from 20-49 years old.

3) Users of hormonal contraceptives and non users of hormonal contraceptives as control group.

4) The users of hormonal contraceptives have been using it for at least 3 months in the past year

5) Are willing to be research subjects and sign an informed consent.

6) Are willing to be interviewed for the sake of data collection.

b. Exclusion Criteria :

1) Diabetes mellitus positive patients based on doctor's diagnosis before using contraception

2) Have suffered from gestational diabetes mellitus based on doctor's diagnosis (gave birth to a baby weigh $>4 \mathrm{~kg}$ )

3) Having history of blood glucose problem (>200 mg/dL).

OGTT examination result is $140-199 \mathrm{mg} / \mathrm{dL}$ or impaired fasting glucose is $100-125 \mathrm{mg} /$ $\mathrm{dL}$ that indicates impaired glucose tolerance 4) Smoking and drinking alcohol.

Cigarette and alcohol may reduce insulin sensitivity and increase the occurrence of insulin resistance

5) Long term drug consumption.

Antidiabetic drugs consumption may reduce blood glucose level. Cortisone and Thiazide may increase blood glucose level.

6) Not willing to participate as research subjects

Sample collection was conducted by using purposive random sampling based on inclusion and exclusion criteria toward hormonal contraceptives acceptors who visit Sangkrah Community Health Center Surakarta. Sample collection by using this method is conducted to obtain sample that represents characteristics of targeted population and controlled confounding factor which is both indentified and unidentified by researchers on the stage of research subjects' selection. Sample is someone who has agreed on informed consent.

The study employed multivariate analysis. The number of sample is obtained from the ratio of sample size and number of independent variables, with:

$$
\mathrm{N}=15-20 \text { subjects per independent variable }
$$

$\mathrm{N}=$ Number of samples

There are three independent variables that are taken into account, namely hormonal contraceptive use, diabetes mellitus risk factors and body mass index. So that,

$\mathrm{N}=15-20$ subjects $\mathrm{x} 3$ independent variables

The samples needed for the study are as many as 45 up to 60 subjects (Murti, 2003).

1. Independent variable : The use of hormonal contraceptives

2. Dependent variable : Blood glucose level

3. Confounding variables :

a. Body Mass Index (BMI)

b. Diabetic Mellitus risk factors

1) Physical activities

2) Food and drink intake/ diet pattern

3) Genetic factors/ family history

4) Weight at birth $<2,5 \mathrm{~kg}$

\section{Operational Definitions}

1. The use of Hormonal Contraceptives

a. Definition: the use of contraceptive types that contains estrogen and progesterone, in the form of injection, pill, as well as implant. The contraceptives have been used for the last three months and have not yet been substituted with other type of contraceptive within the period of time, since impaired glucose tolerance usually emerges after 3 months of use (Hilal, 1985). 
Indonesian Journal of Medicine (2016), 1(1): 1-11 https://doi.org/10.26911/theijmed.2016.01.01.01

b. Measuring instrument: questionnaires with structured interview

c. Measuring scale: nominal

Criteria: users, hormonal contraceptives, more than 3 months

$1=$ yes $; 0=$ no

2. Blood Glucose Level

a. Definition: the amount of glucose measurement which is the final result of carbohydrate digestion in human body metabolism within blood. Respondents' blood glucose level which is measured is random blood glucose level

b. Measuringinstrument: Easy Touch Blood Glucose Test Meter which is equipped with glucostrip dan chip. The capillaries blood sampling is conducted on finger tip (that previously has been cleansed with alcohol) by using lancet.

c. Measuring scale: ratio is presented in $\mathrm{mg} / \mathrm{dL}$

3. Body Mass Index (BMI)

a. Definition: body mass index is an illustration of one's nutrition status.

It is measured through formula body weight in kilogram divided by body height in meter square.

b. Measuring instrument: weight scales and height scales

c. Measuring scale: ratio is presented in $\mathrm{kg} /$ $\mathrm{m}^{2}$

\section{Diabetes Mellitus Risk Factors}

a. Physical activity

Definition: Physical activities that affect blood glucose level are heavy up to medium type of physical activities and exercises. It is conducted at least 30 minutes within a day and three times a week. Examples of some heavy up to medium physical activities are washing clothes, sweeping, ironing, gardening, cleaning windows, walking $3,5 \mathrm{mil} /$ hour, driving car, painting house, and cutting wood (Depkes, 2008).
Measuring instruments: questionnaires with structured interview

Measuring scale: nominal

Criteria: 30 minutes/activity, 3x activities/ week, regular

$0=$ yes $; 1=$ no

b. Food and drink intake/ diet pattern

Definition: good food and drink intake is the one that high in fiber and low in sugar. Three times of big meal (breakfast at 06.0008.00, lunch at 12.00-13.00, and dinner at 18.00-19.00) added with three times of snacks to prevent stomach diseases. In diet assessment toward society it prioritizes more on vegetables and fruit consumption as much as 3-4 portion a day, and granulated sugar is 2-3 spoons a day (Depkes, 2008).

Measuring instruments: questionnaires with structured interview

Measuring scale : nominal

- Meals in a day

Criteria : $\geq 3 \mathrm{x}$ big meals $+3 \mathrm{x}$ snacks

- Fruits/vegetables consumption

o = yes $; 1=$ no

- Granulated sugar consumption

Criteria : >3 tablespoon

$1=$ yes $; 0=$ no

Then the three of them are summed up and categorized by dichotomy:

Sum $\geq 2 \rightarrow 1=$ ya $;<2 \rightarrow 0$ = tidak

c. Birth weight $<2500$ gram

$1=$ yes $; 0=$ no

Someone who was born with Low Birth Weight $<2500$ gram is possible to have pancreas damage so that pancreas capability to produce insulin will be disrupted (Depkes, 2008)

d. Genetic factors/ family history

Criteria : grandmother, grandfather, father, mother, brother, and sister, $1=$ yes $; 0=$ no 


\section{Research Instruments}

1. Questionnaire sheets that includes Informed Consent, data of respondents, and questions to assess the research variables.

2. Body weight scales and body height scales

3. Equipments for blood glucose examination (Easy Touch Blood Test Meter, Glucostrip, alcohol $70 \%$, kapas, lancet)

\section{Procedures:}

1. Anamnesis samples which fit research criteria.

2. Describe it in general about the purpose, benefits, and procedures of the research, including explain that the writer will keep the confidentiality of identity and results obtained.

3. Ask the research subjects to sign informed consent as a statement of willingness to participate in the study.

4. Ask the research subjects to fill out questionnaires and conduct structured interview to identify the identity, obtain the history of birth control use, and other factors.

5. Carry out body weight and body height measurement to calculate BMI

6. Measure the level of random blood glucose (RBG)

7. Process and analyze the data obtained

\section{Data Analysis Technique}

The obtained data were analyzed statistically by using multiple linear regression model multivariate analysis with Statistical Product and Service Sollution (SPSS) for windows. This type of analysis is employed to discover the form of association among variables by controlling the confounding factors to minimize the possibility of wrong conclusion.

The formula :

$\mathrm{Y}=\mathrm{a}+\mathrm{b}_{1} \mathrm{x}_{1}+\mathrm{b}_{2} \mathrm{x}_{2+} \mathrm{b}_{3} \mathrm{x}_{3}$

Information :

$\mathrm{Y}=$ Blood glucose level (mg/dL) $\mathrm{a}=$ constant

$b_{1}=$ regression coefficient for the use of hormonal contraceptives

$\mathrm{x}_{1}=$ the use of hormonal contraceptives

$$
\text { ( } \mathrm{o}=\mathrm{No} ; 1=\mathrm{Yes} \text { ) }
$$

$\mathrm{b}_{2}=$ regression coefficient for BMI

$\mathrm{x}_{2}=$ body mass index $\left(\mathrm{kg} / \mathrm{m}^{2}\right)$

$b_{3}=$ regression coefficient for diabetes mellitus risk factors

$\mathrm{x}_{3}=$ diabetes mellitus risk factors

$$
\text { (o=No;1=Yes) }
$$

Interpretation :

$\mathrm{b}=\mathrm{O} \rightarrow$ no association

$\mathrm{b}>\mathrm{o} \rightarrow$ positive association

(Increase blood glucose level)

$\mathrm{b}<\mathrm{o} \rightarrow$ negative association

(decrease blood glucose level)

Characteristics of categorical data sample were described in frequency (n) and percentage (\%), whereas characteristics of continue data sample were described in mean, standard deviation (SD), minimum, and maximum. Statistical significance of each correlation coefficient (regression b coefficient) is tested afterward with $t$ test and the result is presented by $\mathrm{p}$ value. (Murti, 2003)

\section{RESULTS \\ General Description of the Study}

The working area of Sangkrah Community Health Center covers Semanggi, Sangkrah and Kedung Lumbu urban communities. According to community health center's record by the end of 2012 the total number of active birth control acceptors was as 5,333 people out of 6,622 couples of childbearing age. Afterward, sample was taken from the population that was women of childbearing age who met the criteria of research sample and agreed with inform consent. It obtained 32 acceptors of hormonal contraceptives and 15 women of childbearing age who did 
Indonesian Journal of Medicine (2016), 1(1): 1-11 https://doi.org/10.26911/theijmed.2016.01.01.01

not take hormonal contraceptives as control group.

\section{Research Subjects Characteristics}

1. Research Subjects' Age

From the data obtained, it was discovered that the age of research subjects were varied. The youngest was 20 years old, and the oldest was 49 years old. It was in accordance with inclusion exclusion criteria that obliged the sample should be women of childbearing age (not yet menopause) the ages were between 20 up to 49 years old. Sample of hormonal contraceptives users were between 24-49 years old, whereas for control group were 20-40 years old. The number of subjects who were $<35$ years old were 28 people $(59.57 \%)$ and those who were $\geq 35$ years old were 19 subjects (40. $43 \%)$. The average age of research subjects on hormonal contraceptives acceptors was 34 years and on control group was 29 years. 2. Occupation Distribution

Occupation of the research subjects was assessed by using simple open question to discover how their daily physical activities. From the result of data collection it was found that the frequency of housewives were 28 people $(59.6 \%)$, civil servants were 6 people (12.8\%), labors were 5 orang (10.6\%), dan private sectors were 8 orang (17\%).

All research subjects admitted that they did not carry out heavy physical activities before the examination and almost every household chore was conducted by themselves such as washing clothes, sweeping, mopping, babysitting, and others, however they never exercised and always rode motorized vehicle anywhere to go.

3. Level of Education

The level of education of hormonal contraceptives users was varied. It ranged from primary school to undergraduate degree. From the result of data collection it was discovered that those who were educated up to Primary school were 12 people (25.5\%), Secondary school were 10 people (21.3\%), High school 17 people (36.2\%), Diploma degree 4 people $(8.5 \%)$, and Bachelor degree 4 people $(8.5 \%)$.

The existing data showed that the highest frequency was High school and the lowest frequency was diploma and bachelor degree.

4. The Use of Contraceptives

From Table 1 data it can be observed 3 monthly contraceptive injections was the most favored by hormonal contraceptives users. The following was the list of contraceptives type used by the research sample

Table 1. Type of contraceptives used

\begin{tabular}{lc}
\hline \multicolumn{1}{c}{ Type of Contraceptives Used } & Number \\
\hline IUD & 4 \\
Condome & 1 \\
Pill & 3 \\
Spiral model & 2 \\
Monthly Injection & 5 \\
3 Monthly Injection & 23 \\
Implant & 1 \\
Do not used any contraceptive & 8 \\
Hormonal Contraceptives & 32 \\
Non-Hormonal Contraceptives & 15 \\
\hline
\end{tabular}

5. Nutrition Status of Research Subjects

In the study the result of BMI was obtained from calculation:

$\mathrm{BMI}=\mathrm{BW} / \mathrm{BH}^{2}$

Information:

$\mathrm{BMI}=$ Body Mass Index $\left(\mathrm{kg} / \mathrm{m}^{2}\right)$

BW $=$ Body weight $(\mathrm{kg})$

$\mathrm{BH}=$ Body Height $(\mathrm{m})$

Body weight and body height were obtained based on direct measurement by using body scales and microtoise during the meeting between the researchers and the research subjects..

From the result of the study it was discovered that hormonal contraceptives users were as many as 32 people that in- 
cludes 20 people with normal BMI (18.524.9) and 12 people were overweight (>25) with average BMI was 24.7 out of the amount of 19.2 up to 42.4 . whereas in control group consisted of 15 people, 10 people with normal BMI and 5 people were overweight with the average BMI was 24.2 out of the amount of 19.8 up to 37.1.

As a whole the research subjects who had normal BMI were 30 people out of selected sample, the rest were 17 people and included into overweight category. The average BMI of research subjects both hormonal contraceptives acceptors and control group were included in normal limit criteria. The smallest BMI in the study was 19.2 and the biggest BMI was $42.4 \mathrm{~kg} / \mathrm{m}^{2}$.

\section{Diabetes Mellitus Risk Factors}

Table 2. Diabetes Mellitus Risk Factors

\begin{tabular}{lcc}
\hline DMRF & Frequency & Percentage \\
\hline $\begin{array}{l}\text { Cigarette and } \\
\text { alcohol } \\
\text { consumption }\end{array}$ & 0 & $0 \%$ \\
$\begin{array}{l}\text { History of } \\
\text { previous diseases }\end{array}$ & 0 & $0 \%$ \\
$\begin{array}{l}\text { Drugs } \\
\text { Consumption }\end{array}$ & 0 & $0 \%$ \\
$\begin{array}{l}\text { History of } \\
\text { impaired blood } \\
\text { glucose }\end{array}$ & 0 & $0 \%$ \\
$\begin{array}{l}\text { History of } \\
\text { delivering baby }\end{array}$ & 0 & $0 \%$ \\
$\begin{array}{l}\text { weighed }>4 \mathrm{~kg} \\
\text { History of } \\
\text { gestational } \\
\text { diabetes }\end{array}$ & 0 & $0 \%$ \\
$\begin{array}{l}\text { Birth weight } \\
2,5 \mathrm{~kg}\end{array}$ & 2 & $7.4 \%$ \\
$\begin{array}{l}\text { Family history of } \\
\text { diabetes mellitus }\end{array}$ & 10 & $37 \%$ \\
$\begin{array}{l}\text { Diet (eating } \\
\text { pattern) > the } \\
\text { needs }\end{array}$ & 11 & $40.8 \%$ \\
$\begin{array}{l}\text { Insufficient } \\
\text { physical activities }\end{array}$ & 4 & $14.8 \%$ \\
\hline Total & 27 & $100 \%$ \\
\hline
\end{tabular}

\section{Blood Glucose Level}

Blood glucose level of the research subjects was varied. The average blood glucose level of hormonal contraceptive users was 86.28 $\mathrm{mg} / \mathrm{dL}$. The highest level of blood glucose was $130 \mathrm{mg} / \mathrm{dL}$ whereas the lowest was 42 $\mathrm{mg} / \mathrm{dL}$.

\section{Analysis on Intervariable Association} The analyzed independent variable was hormonal contraceptives use, whereas the dependent variable was blood glucose level. Statistical test which was employed was double linear regression test.

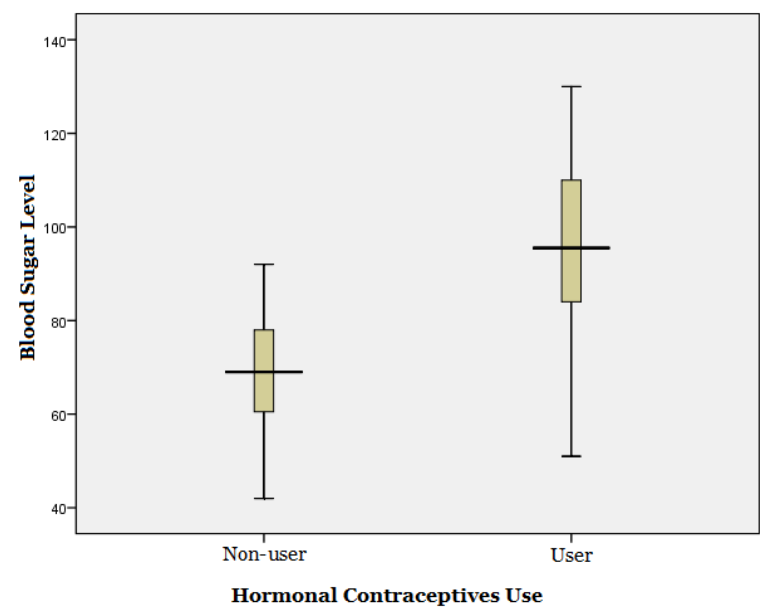

Picture 1. Boxplot Blood Glucose Analysis of relationship between variables

Table 3. The result of data analysis by using double linear regression test.

\begin{tabular}{lcllll}
\hline $\begin{array}{l}\text { Independen } \\
\text { variables }\end{array}$ & Koef $\mathrm{b}$ & $\begin{array}{l}\text { ci } 95 \% \\
\text { Lower } \\
\text { limit }\end{array}$ & $\begin{array}{l}\text { Upper } \\
\text { limit }\end{array}$ & $\mathrm{p}$ \\
\hline Hormonal & 26.18 & 15.03 & 37.33 & $<0.001$ \\
Contraceptives & & & & \\
DMRF & 0.55 & -10.00 & 11.10 & 0.917 \\
BMI & 1.38 & 0.26 & 2.51 & 0.017 \\
N Observed & 47 & & & \\
Adjusted $R^{2}$ & 0.38 & & & \\
\hline
\end{tabular}

From Table 3 it is observed that diabetes mellitus risk factors with the biggest number is diet/eating pattern that exceeds 
Indonesian Journal of Medicine (2016), 1(1): 1-11 https://doi.org/10.26911/theijmed.2016.01.01.01

body needs. The second factor with also big number is family history/ genetic factor.

Adjusted R Square $=0.38$ means that the use of hormonal contraceptives and diabetes mellitus risk factor simultaneously are able to define the variation of blood glucose level as much as 38\%. Table 3 . shows that there is a positive association and statistically significant between hormonal contraceptives use with the increase of blood glucose level. Women of child bearing age who take hormonal contraceptives averagely have blood glucose which is $26 \mathrm{mg} / \mathrm{dl}$ higher than those who do not take hormonal contraceptives $(b=26.18$; CI $95 \%=15.03$ to 37.33$) \mathrm{p}<0.001)$. The estimation of the association has controlled the effect of diabetes mellitus risk factor.

\section{DISCUSSION}

The study entitled "Association between Hormonal Contraception with Blood Glucose Level among Women of Childbearing Age in Sangkrah Community Health Center Surakarta" had been conducted in March- May 2013. Sample was women of Childbearing Age who met the criteria and agreed with the informed consent. Based on the method it found 32 users of hormonal contraceptives and 15 women of childbearing age who did not use hormonal contraceptives as control group. So that the total number of sample was 47 people.

Age distribution of research subjects was varied with the youngest was 20 years old and the oldest was 49 tahun. It is in accordance with inclusion exclusion criteria of the study that obliged sample should be women of childbearing age (not yet menopause) whose age ranged from 20 years old to 49 years old. The age of research subjects was limited on women of child bearing age since menopause women no longer have estrogen and progesterone hormone, it is likely to disturb metabolism.

It can be concluded from the occupation distribution of research subjects that most of the research subjects were housewives. However the other occupations were also very varied. It was similar to the distribution of research subjects' level of education.

Table 1. is a table for types of contraceptives used by contraceptives acceptors in Sangkrah community health center. It was suitable with BKKBN data that the most used hormonal contraceptive is 3 monthly injection. It happens because of support from the government of Indonesia that promotes Family Planning program for free.

BMI was an illustration of nutrition status of the research subjects. It can be seen that the majority of hormonal contraceptives users had normal BMI. However, in Table 3 actually BMI has significant role to influence blood glucose level on women of childbearing age, shown with $\mathrm{p}=0.017$. In other words it is not only hormonal contraceptives that can increase blood glucose level, but also body mass index can, although the significant value is still below the use of hormonal contraceptive which is $\mathrm{p}<$ 0.001 .

On diabetes mellitus risk factors, it is seen that out of numerous factors, diet/ eating pattern has the highest score. It may illustrate that diabetes mellitus is mostly caused by the effect of one's diet/ eating pattern, and then is followed by diabetic family history, which is a genetic factor. Table 3 is a result of data analysis by using SPSS with double linear regression. It is possible to compare that among the three independent variables above the biggest significance value to increase blood glucose level is hormonal contraceptives with $A d$ justed $R$ Square= 0.39 it means that the 
variable of hormonal contraceptives use and diabetes mellitus risk factors collaboratively are able to define the variation of blood glucose level as much as $39 \%$. There is a positive relationship and statistically significant between the use of hormonal contraceptives and the increase of blood sugar level. Women of childbearing age in average have $26 \mathrm{mg} / \mathrm{dL}$ higher than those who do not use hormonal contraceptives $(b=\mathbf{2 6 . 1 8}$; CI 95\% 15.03 up to 37.33; $\mathrm{p}<0.001$ ). It is in accordance with the theory stated by Chrousos in 2007 that progesterone shows antagonist nature toward insulin, therefore the effect of progesterone contraceptives toward metabolism still needs a lot more studies. Progesterone treatment also may reduce insulin sensitivity (Nieuwenhuizen, 1998). Hormonal contraceptives formulation with high dosage of progesterone will show abnormal glucose tolerance test on the users (Stubblefield, 2007).

Various clinical observation and experiment data show that insulin, estrogen, and progesterone interact to each other to affect carbohydrate metabolism on the level of glucose transportation (Valdes dan ElkindHirsch 1991).

Estrogen induces glucose tolerance because of direct effect of estrogen to pancreas, in which specific estrogen receptor has been identified, however the effect regression can not be explained yet. Glucose level reduction from estrogen effect may happen because of the reduction of glucogenolysis effect and from glucogeneogenesis within cell so that it leads to the increase of liver gluconeogenesis. Estrogen hampers the induction of glucagon secretion because of arginine (Hilal, 1985).

The increasing level of estrogen and progesterone hormones on women who use oral combination of hormonal contraceptives therapy may influence glucose toleran- ce and insulin sensitivity (Godsland et al. 1992).

For risk factors of coefficient $b$ diabetes mellitus the result is positive, it means the association which is established between diabetes risk factors and blood glucose level is positive, meaning to say that if there is risk factors of diabetes mellitus then blood glucose level will increase as much as 0.6 $\mathrm{mg} / \mathrm{dL}$. However the result of the study was not statistically significant since the signifycant value was too big which was above 0.05 (with $\mathrm{p}=0.917$ ).

The study has some limitation those are data collection on general condition of the respondents were only obtained from interview without any verification, and body weight, body height and blood glucose level examination were only conducted once, therefore it was possible to represent not the real condition. It happened due to limited time. The number of respondents had met the calculation on sample formulation, however by using bigger sample it is expected that the study result may reduce the bias and is able to represent more on the population so it is possible to be generalized. Therefore it needs to conduct bigger study with more number of samples.

\begin{tabular}{l}
\hline REFERENCE \\
\hline Ahrendt HJ, Bühling KJ (2010). Estrogen \\
Free Contraception: Progestin-only- \\
systems. J Reproductions Endocrinal. \\
7 (Sonderheft 1). \\
Albar E (2009). Contraception. In: Science \\
Content ed 2. Jakarta: PT Bina Library \\
Sarwono Prawirohardjo. \\
BKKBN (2012). Number of Active Women \\
Participants Family Planning in Janu- \\
ary 2012. www.bkkbn.go.id. \\
Central Bureau of Statistics (2012). The \\
percentage of married women aged 15-
\end{tabular}


Indonesian Journal of Medicine (2016), 1(1): 1-11 https://doi.org/10.26911/theijmed.2016.01.01.01

49 who use birth control. Accessed February 2013.

- Accessed February 2013.

Chrousos GP (2007). The Gonadal Hormone and Inhibitors; Katzung on Basic and Clinical Pharmacology; 10th ed.; The McGraw-Hill Co. Inc: 664-71.

Department of Health (2008). Technical manual measurement of risk factors for diabetes mellitus. Jakarta: Ministry of Health.

Glacier, Gebbie A. (2006). Family Planning and Reproductive Health. Issue 4. Jakarta: EGC.

Godsland IF, Walton C, C Felton, Proudler A, Patel A and Wynn V (1992) Insulin resistance, secretion, and metabolism in users of oral contraceptives. J Clin Endocrinol Metab 74: 64-70.

Guyton AC, Hall JE (2008). Textbook of medical physiology. $11^{\text {th }}$ Edition. Jakarta: EGC.

Hall PE (1994). The introduction of Cyclofem into National Family Planning Programmes: Experience from Studies in Indonesia, Jamaica, Mexico, Thailand and Tunisia. World Health Organization Task Force on Study on the Introduction and Transfer of Technologies for Fertility Regulation. Contraception 49: 489-507.

Hardjoeno H (2003). Interpretation of Test Results Diagnostic Laboratory. Jakarta: EGC.

HA Harper, Victor WR, Peter AM (2003). Review of physiological chemistry. California: Lange Medical Publications.

Hilal M (1985). Oral Contraception and Carbohydrate metabolism-the physiopathological explanation. http: www. ncbi.nlm.nih.gov. February 2013.
Lemon P, K Burke (2002). Medical Surgical Nursing: critical thinking in client care (2th Ed). Prenince Hall. New Jersey.

Manuaba IBG (1998). Obstetrics, Gynecology and Family Planning for Education Midwives. Jakarta: EGC.

Murti B (2003). Principles and Methods of Study on the Epidemiology. Yogyakarta: Gadjah Mada University Press.

Perkeni (Society of Endocrinology Indonesia) (2006). Consensus of Diabetes Mellitus Management in Indonesia.

Schteingart DE (2006). The principle mechanism of endocrine and metabolic control. In: Price SA, LM Wilson. Pathophysiology of concept clinical disease processes. Jakarta: EGC Book Medical Publishers: 1203.

Siswosudarmo HR, HM Anwar, Emilia O (2001).Contraceptive technology. Yogyakarta: Gadjah Mada University Press.

Stubblefield PG (2007). Carr-Ellis S, Kapp N. Family Planning, on Berek and Novak's Gynecology; 14th ed .; Lippincott Williams and Wilkins: 247-312.

Stryer L (2000). Mohamad Sadikin alih bahasa et al. Glycogen metabolism. In Biochemistry. Jakarta: EGC.

Tjay TH, Rahardja K (2007a). Antikonseptiva. In: Drugs important. Jakarta: PT Elex Media Komputindo: 712-722.

Valdes CT, Elkind-Hirsch KE (1991) Intravenous glucose tolerance test-derived insulin sensitivity changes during the menstrual cycle. J Clin Endocrinol Metab 72: 642-646.

Widodo FY (2012). The effect of our combined contraceptive pills on blood glucose levels. Accessed March 14, 2013.

Wiegratz I, Christian JT (2011). Hormonal contraception-what kind, when, and 
for Whom? Dtsch Arztebl Int 108 (28-29): 495-506.

Wiegratz I, Thaler CJ (2011). Hormonal Contraception-What Kind, When, and for Whom? Dtsch Arztebl Int 108 (2829): 495-506.
Wulansari HP (2006). Variety of methods of contraception. Jakarta: EGC.

Zieman M, Hatcher RA, Cwiak C (2010). Managing the contraception for your pocket in 2010-2012. Accessed February 2013. 